\title{
Effects of micro-environmental conditions and forest disturbance on the establishment of two Andean palms in Ecuador
}

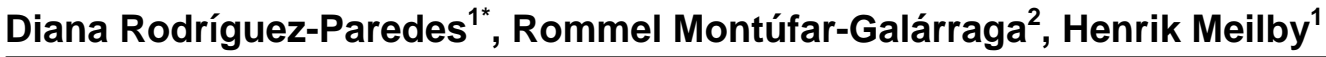 \\ ${ }^{1}$ Forest \& Landscape, University of Copenhagen, Copenhagen, Denmark; *Corresponding Author: rodriguezp.diana@gmail.com \\ ${ }^{2}$ Ecology and Genetics, Pontificia Universidad Católica del Ecuador, Quito, Ecuador
}

Received 17 September 2012; revised 20 October 2012; accepted 28 October 2012

\section{ABSTRACT}

The wax palm (Ceroxylon echinulatum) and palm heart (Prestoea acuminata) are key elements in Andean natural forests. This ecosystem is threatened by deforestation and habitat degradation, thus, it is vital to explore the impact of anthropogenic activities on the ecological structure and preferences of these species in order to develop proper conservation strategies. Fiftyseven $400 \mathrm{~m}^{2}$ plots were established in two forest areas, a disturbed forest ( $n=30$ plots) and an undisturbed forest ( $n=27$ plots) in the Ecuadorean Andes. Nine micro-environmental variables and the number of individuals of $C$. echinulatum and $P$. acuminata in five size classes were recorded in each plot. Logistic regression models helped identify environmental variables that influence the establishment of the species. Results showed that different micro-environmental variables determined the presence of different size classes. Both species were benefitted by the environmental conditions of the disturbed forest. Light availability was important for the establishment of both species, especially for the canopy species (C. echinulatum). This palm was negatively affected by the variable "fallen wood", while $P$. acuminata was negatively affected mainly by the steepness of the terrain. The environmental variables for the successful establishment of the studied species that were identified by this study provide clues for the sustainable management of $C$. echinulatum and $P$. acuminata in Andean forests.

Keywords: Andean Forest; Ceroxylon; Forest Disturbance; Micro-Environmental Variables; Palm Establishment; Prestoea; Sustainable Management

\section{INTRODUCTION}

The palm family is important to humans as a diverse source of non-timber forest products [1,2]; however unsustainable harvesting and deforestation are threatening the permanence of harvested species in natural forests [3-5]. Human activities modify environmental conditions in forest remnants thereby also altering the conditions under which palm species regenerate and establish [6,7].

South America has a high diversity of palms with 457 species and 50 genera [8]. Part of this diversity is found in the Andes above 1000 m.a.s.l where palms represent $37 \%$ of the palm genera and $15 \%$ of the palm species reported in the Americas [9]. Four genera have their center of distribution in the Andes: Aiphanes, Ceroxylon, Parajubaea and Wettinia; among which Ceroxylon is endemic to the Andes [9]. In the Ecuadorean Andes, the most economically important palm genera are Ceroxylon and Prestoea. Leaves of the former genus are used as raw material for handicraft in Easter and unfolded leaves of the latter genus are source of palm heart or palmito [1013].

Palms respond to environmental heterogeneity at both large and small scales. At the large scale, the distribution of palms is mainly determined by climate [14-16], geological regions [17], historical legacies [14,18,19], and to a smaller extent by edaphic characteristics [20-22], and dispersal dynamics [23]. Small scale environmental heterogeneity $\left(0.1\right.$ to $10 \mathrm{~m}^{2}$; [15]) is important for the distribution and diversity of palms $[15,24,25]$. Sources of micro-environmental variation include canopy heterogeneity, inter- and intra-specific relations, edaphic conditions $(\mathrm{pH}$, litter) and topography. Among these variables, canopy heterogeneity is suggested as an important source of variation since it can modify variables such as light intensity and quality, soil, microtopography, risk of damage, pollination and seed dispersal [15].

The dependence of many palms on humidity makes the Andean cloud forests important for palm species 
growing at high elevations. Unfortunately, this kind of forests (characterized by a constant mist and high biodiversity and endemism) is highly threatened by deforestation [26-28]. Environmental conditions of forests may change as a result of forest fragmentation [4], logging [26], harvesting of selected products [29], and/or other extractive activities affecting plant and animal population dynamics and distribution [6,30,31]. The effects of deforestation on palm populations may be better understood when analyzed separately for each life stage of the individuals since some palm species change their environmental preferences during ontogeny [32]. Due to the threatened status of Andean cloud forest palms and their importance in local ecosystems, it is necessary to understand the effects of different environmental conditions on the regeneration, establishment and growth of harvested palm species in order to predict consequences of environmental changes on populations and as a basis for suggesting sustainable management strategies that protect the target species and natural forest dynamics.

Accordingly, the objective of this study is to identify micro-environmental variables that determine the distribution of the different life stages of Ceroxylon echinulatum and Prestoea acuminata growing in the cloud forests of the Ecuadorean Andes. Additionally, this work aims to compare the establishment requirements of palm species with different habits (canopy and understory) and in forests with different degrees of disturbance (disturbed and undisturbed forest). The selection of the species was based on the following criteria: a) both species are important components of the Andean forest due to their abundance and the resources they provide to the local fauna $[10,33]$, b) their natural populations are threatened by deforestation, habitat degradation, and harvesting $[34,35]$, c) both species are important for the local economy [1], and d) there is a lack of information about their ecology that impedes the development of proper management plans.

\section{STUDY SITE}

The study took place in the north-western part of the Pichincha province (Figure 1). This region contains a cloud forest ecosystem at elevations ranging from 1500 to 2000 m.a.s.l. with monthly mean temperatures ranging from $18^{\circ} \mathrm{C}$ to $24^{\circ} \mathrm{C}$. The rainy season can last for 10 months with maximum precipitation values in April and November. The dry season starts between July and August and lasts for two to three months [36]. In this region two localities characterized by different levels of human disturbance were selected: a) Inti Llacta reserve (disturbed forest), and b) Rio Bravo Reserve (undisturbed forest). The two localities are located ca. $20 \mathrm{~km}$ from each other.
Inti Llacta (Miraflores community) is a private reserve $\left(00^{\circ} 02^{\prime} \mathrm{N}, 78^{\circ} 43^{\prime} \mathrm{W} ; 1875 \pm 16.2\right.$ m.a.s.l) with ca. 100 ha of secondary cloud forest. This forest reserve is a mosaic of forests patches with different levels of regeneration and pasture. In this forest, selective logging and harvesting of palms were undertaken for several years until the creation of the reserve in 1982. Particularly, in the 1970's and 1980's the natural populations of $P$. acuminata were heavily harvested due to the high demand for palm heart [37]. Leaves of $C$. echinulatum were harvested until 2009 when the government of Ecuador banned the extraction from natural forests. Illegal extraction of both products from the forest still happens along with deforestation, mining, floriculture and poultry farming, causing environmental damages [34].

Rio Bravo is a private reserve $\left(00^{\circ} 04^{\prime} \mathrm{S}, 78^{\circ} 44^{\prime} \mathrm{W} ; 1690\right.$ \pm 72.1 m.a.s.l) with ca. 4000 ha of undisturbed cloud forest (Cantón San Miguel de los Bancos) and is part of the Mindo-Nambillo protected area (19.200 ha; [34]). Due to its difficult access, the area has been relatively isolated from human activities, and therefore the forest is in a well conserved condition with no reported extraction activities.

\section{STUDY SPECIES}

Ceroxylon echinulatum Galeano is a canopy (10 - 30 $\mathrm{m}$ tall; diameter 15 - $30 \mathrm{~cm}$ ), solitary and dioecious palm [38]. Stems are covered with a layer of wax that usually have oblique ring-shaped leaf scars. This palm species prefers humid and rainy mountain regions of Ecuador and northern Perú between 1600 and 2200 m.a.s.l. Unfolded young leaves (spear leaf or cogollo) are harvested once or twice a year to weave handicrafts for Easter and/or Christmas. This harvesting activity affects mainly stem-less individuals with leaf size larger than $2 \mathrm{~m}$ because of the easy access to the spear leaf. In Ecuador, the trade of handicrafts made with $C$. echinulatum's leaves is an economic activity that represents an important source of income to local communities and artisans (Montúfar, unpublished data).

Prestoea acuminata (Willd.) H. E. Moore is a midstory species, monoecious, with solitary or clustered stems that can reach heights of $6-15 \mathrm{~m}$ and diameters of $4-20 \mathrm{~cm}$ [39]. The species has a wide distribution, growing in mountain regions of the Antilles and Central America; and premontane and montane areas (1000 - 2000 m.a.s.l) of the Andean slopes from Venezuela to Bolivia [39]. Unfolded leaves (apical meristem) of this species are harvested and sold as palm hearts in local communities [10]. The extraction is done any time through the year with no discrimination between reproductive and nonreproductive individuals. 


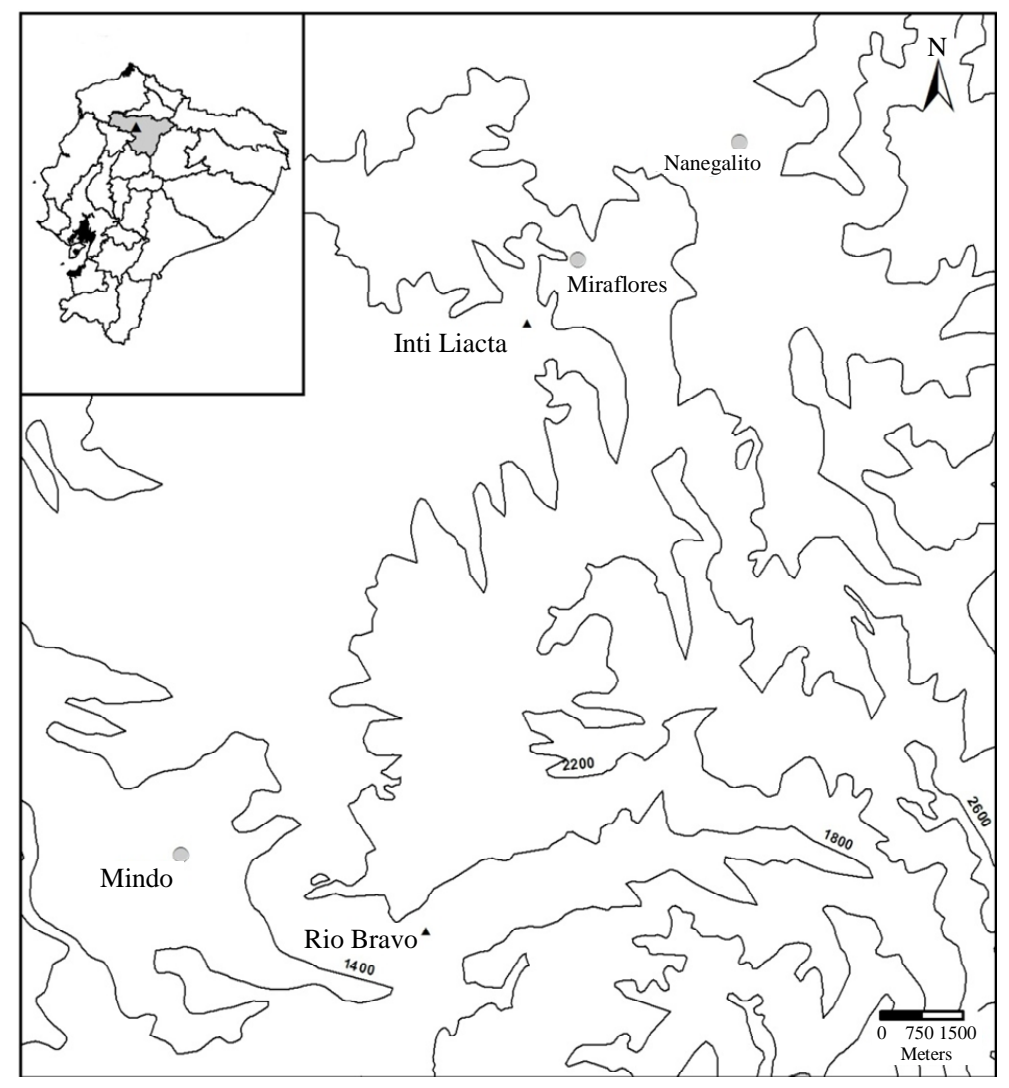

Figure 1. Study area. Black triangles are the study sites; gray circles are closest towns to the study sites.

\section{METHODS}

\subsection{Census}

Data were collected in March and April 2010. A plotbased inventory of $C$. echinulatum and P. acuminata was carried out in disturbed (Inti Llacta reserve) and undisturbed (Río Bravo reserve) forests. Individuals of $C$. echinulatum were classified as: 1) seedlings (individuals with undivided leaves), 2) juveniles 1 (individuals without stem and with pinnate leaves shorter than $2 \mathrm{~m}$ ), 3) juveniles 2 (individuals without stem and with pinnate leaves longer than $2 \mathrm{~m}$ ), 4) subadults (individuals with stem but without reproductive structures) and 5) adults (stemmed reproductive individuals). P. acuminata individuals were classified as: 1 ) seedlings, 2) juveniles 1 (individuals with at least one pinnate leaf and/or with a single stem), 3) juveniles 2 (individuals with clones), 4) subadults (individuals with clones, stem and crownshaft), 5) reproductive adults with stem and/or clones.

For the data collection, a total of fifty-seven $400 \mathrm{~m}^{2}$ $(20 \mathrm{~m} \times 20 \mathrm{~m})$ plots were established (30 plots in disturbed forest and 27 plots in undisturbed forest) along two linear transects in each forest (total of 4) with a distance between plots centers of $40 \mathrm{~m}$. In both forests transects were located at a minimum distance of $120 \mathrm{~m}$ from each other and each transect was about $600 \mathrm{~m}$ long and included about 15 plots of $400 \mathrm{~m}^{2}$. This design for data collection allowed covering the topographic and environmental variation of the studied places. The number of adults of both species and subadults of C. echinulatum were recorded in the $400 \mathrm{~m}^{2}$ plots, juveniles of both species and subadults of $P$. acuminata were recorded in $100 \mathrm{~m}^{2}(10 \mathrm{~m} \times 10 \mathrm{~m})$ plots nested within the $400 \mathrm{~m}^{2}$ plots, and seedlings were recorded in five subplots of $4 \mathrm{~m}^{2}(2 \mathrm{~m} \times 2 \mathrm{~m})$ located in the center and in the corners of each $400 \mathrm{~m}^{2}$ plot.

\subsection{Variables Measured}

Two types of variables were measured within each 400 $\mathrm{m}^{2}$ plot: topo-edaphic variables and forest structure variables. The topo-edaphic variables were: 1 ) aspect (measured using compass, degrees), 2) slope inclination (measured in the steepest area of the $400 \mathrm{~m}^{2}$ plot using a clinometer, Sunnto Tandem; degrees), 3) leaf cover (percentage of soil covered by leaf litter in each $4 \mathrm{~m}^{2}$ plot) and 4) leaf depth (number of leaves on the forest floor pierced with a pointed stick [40] in the center of each 4 $\mathrm{m}^{2}$ plot). The forests structure variables were: 1 ) canopy height (height of the tree with the largest diameter 
measured using a clinometer Sunnto Tandem; meters), 2) basal area (of all trees with diameter at breast height $(\mathrm{DBH})>10 \mathrm{~cm}$ measured using a measuring tape; $\mathrm{m}^{2}, 3$ ) canopy openness (measured in the center of each of the 4 $\mathrm{m}^{2}$ plots using the canopy-scope scoring system; percent; [41]), 4) gaps (absence or presence), and 5) fallen wood (number of trees or branches with diameter $>10 \mathrm{~cm}$ lying on the floor).

\subsection{Statistical Analyses}

Aspect values $(\alpha)$ were converted into north exposures (cosine $\alpha$ ) and east exposures (sine $\alpha$ ), i.e. the lower the value of north exposure, the farther from north the aspect; similarly, for east exposure in relation to east. The five measurements of each of the variables "leaf cover", "leaf depth" and "canopy openness" obtained for each $400 \mathrm{~m}^{2}$ plot were averaged with the purpose of obtaining a single value per $400 \mathrm{~m}^{2}$ plot to be used in the statistical analyses. T-tests were done in order to identify significant differences between densities of different life stages and environmental variables between forests.

Variables that best explained the distribution (presence) of each of the life stages of the two palm species were selected using logistic regression models. In addition to the micro-environmental variables, the presence of adults was also included as a potential explanatory variable for seedlings. A Principal Component Analysis (PCA) was carried out in order to identify uncorrelated factors and thereby reduce the number of explanatory variables. PCA results were used as a reference for selecting the variables to be included in the final logistic analyses. Selection of independent variables in the logistic models was based on the significance level of the parameter estimates ( $p$-value < 0.05), the Akaike Information Criterion (AIC), log-likelihood values and the percentage concor- dance of the model. Models with independent variables that were almost uncorrelated with each other were preferred. Statistical analyses were done using the software package SAS version 9.2 (SAS Institute, INC., Cary, NC).

\section{RESULTS}

\subsection{Description of the Forests}

Statistically significant differences between forests were observed for the majority of the environmental variables (Table 1), the disturbed forest showing greater values for most of them. In the undisturbed forest the terrain was steeper than in the disturbed forest. The light related variables, “canopy openness” and "gaps”, were found to have larger values in the disturbed forest than in the undisturbed forest, but the difference was significant only for the former variable. The variable “canopy height” had larger values in the undisturbed forest.

\subsection{Population Structure within the Forest}

Population structures of both $C$. echinulatum and $P$. acuminata differed significantly between disturbed and undisturbed forests (Figures 2 and 3). All life stages of $C$. echinulatum had more individuals in the disturbed forest than in the undisturbed forest. Early life stages of $P$. acuminata were more abundant in the undisturbed forest than in the disturbed forest but the opposite pattern was observed in later life stages. In general, and irrespective of forest type, the density of individuals of $C$. echinulatum decreased towards older life stages. This was also the case for $P$. acuminata with the exception of subadults in the disturbed forest and adults in the undisturbed forest, which were more abundant than previous life stages. For both species in both forests, about $90 \%$ of the individuals were seedlings. By comparing densities of adult individuals

Table 1. Comparison of the environmental variables between disturbed and undisturbed forest using a t-test.

\begin{tabular}{|c|c|c|c|c|c|c|c|}
\hline & \multicolumn{3}{|c|}{ Disturbed forest } & \multicolumn{3}{|c|}{ Undisturbed forest } & \multirow{2}{*}{$\operatorname{Pr}>|t|$} \\
\hline & $\mathrm{N}$ & Mean & Stdev & $\mathrm{N}$ & Mean & Stdev & \\
\hline Leaf cover (\%) & 30 & 87.133 & 11.584 & 27 & 74.389 & 20.701 & 0.007 \\
\hline Leaf depth (\#) & 30 & 1.793 & 1.191 & 27 & 1.102 & 0.610 & 0.008 \\
\hline Canopy height (m) & 30 & 17.238 & 5.411 & 27 & 20.049 & 5.475 & 0.057 \\
\hline Canopy openness (\%) & 30 & 4.720 & 6.212 & 27 & 2.089 & 2.736 & 0.042 \\
\hline Gaps (\#) & 30 & 0.600 & 0.498 & 27 & 0.519 & 0.509 & 0.544 \\
\hline Fallen trees (\#) & 30 & 4.500 & 2.688 & 27 & 6.778 & 4.353 & 0.024 \\
\hline
\end{tabular}

$\mathrm{N}=$ number of plots; Stdev = standard deviation . 


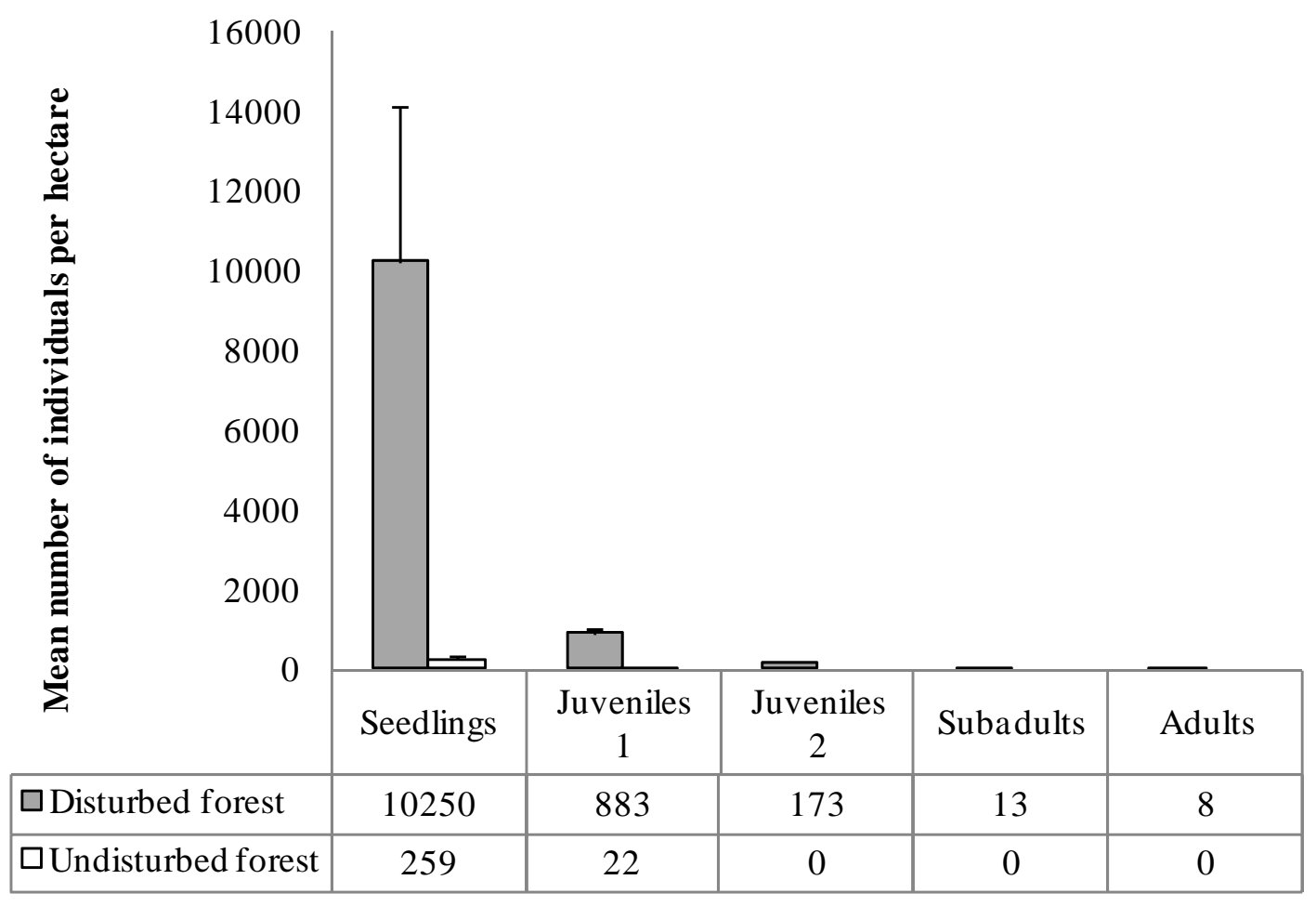

Figure 2. Population structure of Ceroxylon echinulatum in two forests types (disturbed and undisturbed). $\mathrm{N}=$ 57. T-tests: Seedlings $p=0.015$; juveniles $1 p<0.001$. Error Bars $=$ standard errors.

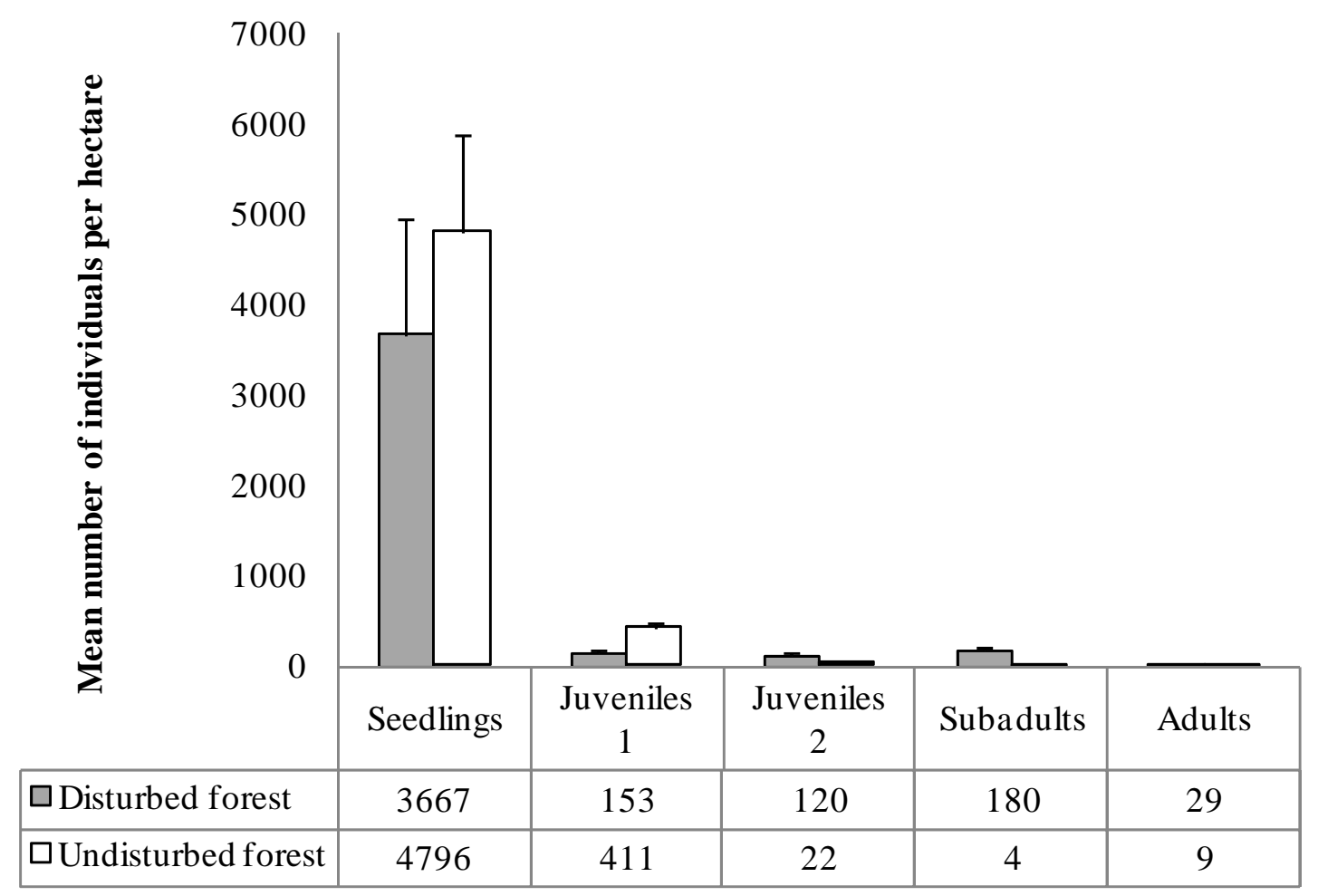

Figure 3. Population structure of Prestoea acuminata in two forests types (disturbed and undisturbed). $\mathrm{N}=57$. T-tests: Seedlings $p=0.507$; Juveniles $1 p=0.001$; Juveniles $2 p=0.003$; Subadults $p<0.001$; Adults $p=0.02$. Error Bars $=$ standard errors. 
and seedlings of $C$. echinulatum in the disturbed forest, it appeared that only about $0.081 \%$ of the seedlings are likely to reach the adult stage. A similar survival rate could not be estimated for the undisturbed forest because no adults were found in the plots. For $P$. acuminata the apparent survival rates were also low; in disturbed forest only $0.79 \%$ of all seedlings were likely to become adults; in undisturbed forest the estimated survival rate was only $0.19 \%$.

\subsection{Logistic Models: Variables Determining Distribution}

Different variables were found to determine the distribution of different life stages of the studied species (Tables 2 and 3). For C. echinulatum four out of the five forest structure variables (basal area, canopy height, canopy openness and fallen wood) appeared to affect the majority of the life stages. Among the variables related to the availability of light, "canopy openness" and "canopy height” influenced the presence of most of the life stages. Rich-lit environ- ments appeared to benefit the establishment of the spe- cies, but the presence of gaps did not influence any of the life stages for $C$. echinulatum. Moreover, the absence of adults did not influence the presence of seedlings of this species significantly.

The parameters of the variables included in the best logistic models for $P$. acuminata were not all significantly different from zero at the $5 \%$ level. This was the case for the life stages “juveniles 1" and "adults". Nevertheless it was decided to include these models since their $p$-values were not far from the applied significance level (5\%). For $P$. acuminata, the variable "slope" appeared to be the only variable that generally had a negative effect on the presence of the species. Among variables related to light conditions, “canopy openness” was important only for subadults and the presence of gaps was negatively related to the presence of adults. Contrary to the findings for $C$. echinulatum, the absence of adults of $P$. acuminata did appear to influence the presence of seedlings of this species. Other variables that influenced the distribution of at least one life stage were: basal area, east exposure and leaf cover.

\section{DISCUSSION}

\subsection{Variables Determining the Presence of Seedlings}

As expected for this life stage, light related variables did not influence the presence of seedlings of any of the studied species since both are shade tolerant species that can germinate and establish under closed canopy conditions. Some studies found that seedlings of both $P$. acuminata and $C$. echinulatum can grow in places characterized by a wide range of light conditions [10,33,42], but full light exposure may have a negative effect on the establishment of $C$. echinulatum [33]. Other factors such

Table 2. Logistic regression models predicting the probability of presence of individuals of Ceroxylon echinulatum in each life stage. Model: probability $=\exp (\mathrm{a}+\mathrm{b}(\mathrm{x})) /(1+\exp (\mathrm{a}+\mathrm{b}(\mathrm{x}))$.

\begin{tabular}{|c|c|c|c|c|c|c|c|c|c|c|c|}
\hline & $\mathrm{a}$ & Basal area & $\begin{array}{c}\text { Canopy } \\
\text { height }\end{array}$ & $\begin{array}{c}\text { Canopy } \\
\text { openness }\end{array}$ & $\begin{array}{c}\text { East } \\
\text { exposure }\end{array}$ & $\begin{array}{l}\text { Fallen } \\
\text { wood }\end{array}$ & Gaps $^{*}$ & $\begin{array}{l}\text { Leaf } \\
\text { Cover }\end{array}$ & Slope & $\begin{array}{c}\text { Absence } \\
\text { adults }\end{array}$ & Concordant \\
\hline & & $\left(\mathrm{m}^{2} / \mathrm{ha}\right)$ & (m) & (\%) & & (\#) & & (\%) & $\left({ }^{\circ}\right)$ & & $\%$ \\
\hline Seedling & 1.268 & 0.059 & -0.129 & & & & & & & & 74.2 \\
\hline sterror & 1.322 & 0.027 & 0.061 & & & & & & & & \\
\hline$p$ & 0.337 & 0.028 & 0.036 & & & & & & & & \\
\hline Juvenile1 & -1.543 & 0.098 & & 0.312 & 1.951 & -0.318 & & & & & 88.9 \\
\hline sterror & 1.216 & 0.037 & & 0.153 & 0.671 & 0.127 & & & & & \\
\hline$p$ & 0.204 & 0.009 & & 0.041 & 0.004 & 0.013 & & & & & \\
\hline Juvenile2 & -2.138 & 0.062 & & 0.344 & & -0.323 & & & & & 84.3 \\
\hline sterror & 1.18 & 0.029 & & 0.138 & & 0.133 & & & & & \\
\hline Subadult & 5.072 & & -0.241 & 0.135 & & & & & -0.095 & & 81.8 \\
\hline sterror & 2.409 & & 0.101 & 0.071 & & & & & 0.042 & & \\
\hline$p$ & 0.035 & & 0.017 & 0.055 & & & & & 0.025 & & \\
\hline Adults & 9.208 & & -0.551 & & & -1.012 & & & & & 95 \\
\hline sterror & 4.247 & & 0.246 & & & 0.489 & & & & & \\
\hline$p$ & 0.03 & & 0.025 & & & 0.038 & & & & & \\
\hline
\end{tabular}

$\mathrm{a}=$ intercept. ${ }^{*}$ presence gaps. Sterror $=$ standard error. 
Table 3. Logistic regression models predicting the probability of presence of individuals of Prestoea acuminata in each life stage. Model: probability $=\exp (\mathrm{a}+\mathrm{b}(\mathrm{x})) /(1+\exp (\mathrm{a}+\mathrm{b}(\mathrm{x}))$.

\begin{tabular}{|c|c|c|c|c|c|c|c|c|c|c|c|}
\hline & $\mathrm{a}$ & Basal area & $\begin{array}{l}\text { Canopy } \\
\text { height }\end{array}$ & $\begin{array}{c}\text { Canopy } \\
\text { openness }\end{array}$ & $\begin{array}{c}\text { East } \\
\text { exposure }\end{array}$ & $\begin{array}{l}\text { Fallen } \\
\text { wood }\end{array}$ & Gaps* & Leaf Cover & Slope & $\begin{array}{l}\text { Absence } \\
\text { adults }\end{array}$ & concordant \\
\hline & & $\left(\mathrm{m}^{2} / \mathrm{ha}\right)$ & (m) & (\%) & & $(\#)$ & & (\%) & $\left({ }^{\circ}\right)$ & & $\%$ \\
\hline Seedling & 5.863 & & & & & & & -0.055 & & -0.674 & 72.9 \\
\hline sterror & 2.367 & & & & & & & 0.027 & & 0.360 & \\
\hline $\mathrm{p}$ & 0.013 & & & & & & & 0.038 & & 0.061 & \\
\hline Juvenile 1 & 3.268 & & & & & & & & -0.066 & & 65.1 \\
\hline sterror & 1.281 & & & & & & & & 0.035 & & \\
\hline $\mathrm{p}$ & 0.011 & & & & & & & & 0.060 & & \\
\hline Juvenile 2 & -0.478 & & & & 0.893 & & & & & & 64.4 \\
\hline sterror & 0.295 & & & & 0.446 & & & & & & \\
\hline $\mathrm{p}$ & 0.105 & & & & 0.045 & & & & & & \\
\hline Subadult & -1.576 & 0.089 & & 0.258 & & & & & -0.079 & & 85.2 \\
\hline sterror & 1.451 & 0.032 & & 0.117 & & & & & 0.036 & & \\
\hline $\mathrm{p}$ & 0.277 & 0.005 & & 0.028 & & & & & 0.030 & & \\
\hline Adult & 1.455 & & & & & & -0.551 & & -0.054 & & 70.1 \\
\hline sterror & 0.978 & & & & & & 0.289 & & 0.030 & & \\
\hline $\mathrm{p}$ & 0.137 & & & & & & 0.057 & & 0.066 & & \\
\hline
\end{tabular}

a = intercept; ${ }^{*}$ presence gaps; Sterror = standard error.

as temperature or humidity are presumably more important for seedling establishment in both $C$. echinulatum and $P$. acuminata. Madriñán and Schultes [43] suggested that the germination of Ceroxylon quinduense required special conditions of high humidity. Leaf litter may be an important element determining the establishment of seedlings since it modifies micro-habitat conditions [44,45], protects seeds from predation [46], or enhances fungi attack [47]. In accordance with the study by Didham and Lawton [48], the present study found more leaf litter in the disturbed forest. The low abundance of $P$. acuminata in this forest may be to a negative effect of leaf litter on germination.

A high canopy was found to negatively affect the establishment of seedlings of C. echinulatum. This result may be explained by the negative relation between the number of adults and the canopy height as also reported by Paredes [49] on western slopes for the same species. The lower height of the canopy in the disturbed forest could explain the higher number of seedlings of $C$. echinulatum in this forest. For $P$. acuminata the presence of seedlings did depend on the absence of adults. This result suggests that spatial dispersion of $P$. acuminata is very low. As a consequence, the risk of death for seeds and seedling of this species may be high according to Janzen and Con- nell's model [50].

\subsection{Variables Determining the Presence of Juveniles}

Shade tolerance in palms generally declines with ontogeny [32]. This characteristic may be particularly evident for canopy palms whose adult form is found in richlit canopy environments [51,52]. This is in agreement with this study, where light availability was found to positively affect the presence of juveniles of the canopy species (C. echinulatum) only.

Mortality as a result of fallen pieces of wood may be a good indicator of conditions affecting the establishment of juveniles of $C$. echinulatum in the undisturbed forest. According to Laurance i.e. [31] more tree damage is expected in disturbed forests as a result of lower water availability and stronger wind impact. Accordingly, the disturbed forest was expected to have more "fallen wood" than the undisturbed forest, but the opposite result was found in this study. The reason may be related to specific characteristics of the former forest such as the steepness of the terrain and/or the predominant plant species. Fallen wood may also affect juveniles of $P$. acuminata, however; variables such as "slope" of the terrain and "as- 
pect" seemed to be more important. The steepness of the terrain in the undisturbed forest did not favor the establishment of individuals of $P$. acuminata, probably as a result of mortality due to soil instability and small landslides. As expected, juveniles 1 of $P$. acuminata were affected by the steepness of the terrain since they are small in size and/or have only one slim stem. Any damage to a single-stemmed individual would kill it [53].

The variable "east exposure" appeared to influence the abundance of juveniles of both species positively. Other studies also reported an effect of aspect on the distribution of $C$. echinulatum [54] and P. acuminata [55]. The variable "basal area" positively affected the early stages of $C$. echinulatum. This result is in agreement with Anthelme i.e. [33], who found that the basal area of regenerating individuals (20 - $30 \mathrm{~cm}$ DBH) positively affected the abundance of $C$. echinulatum in disturbed forests.

\subsection{Variables Determining the Presence of Subadults}

In $C$. echinulatum, the end of the establishment phase and the beginning of the subadult phase is determined by the appearance of the stem [32]. By contrast, in P. acuminata stem diameter and height increase simultaneously [56]. Regardless of the differences in the stem developments, both species showed faster growth early in the subadult phase $[57,58]$. In this phase of fast growth, light availability is believed to be important for the establishment of subadults especially for the canopy species that needs the rich-lit condition above the canopy to develop reproductive structures. As expected, the distribution of subadults of both species was positively related with light availability. The negative relationship between the abundance of subadults of $C$. echinulatum and the light related variable "canopy height" provides additional evidence of the dependence of this canopy palm on rich-lit environments.

"Slope" appeared to be one of the determinants of the presence of subadults for both species. For C. echinulatum this may be explained by low recruitment into this stage, as previous stem-less stages may be more vulnerable to die from landslides. In the case of P. acuminata, a partial explanation may be that the small diameter of its stem makes it easy to bend. In the case of single-stem individuals, the bending may cause death

\subsection{Variables Determining the Presence of Adults}

Adults of the canopy species ( $C$. echinulatum) are believed to rely more on well-lit environments than adults of the midstory species (P. acuminata) [52]. Light related variables such as gaps and canopy openness were not part of the final model for the canopy palm; but the importance of light for adult establishment for this species was indicated by the variable canopy height which was part of the final model. Under tall canopies, individuals have to grow more before reaching the full light above the canopy, which will give them the energy to produce reproductive organs. Similar results were found by Paredes [49] for the same species in the eastern Andes. The present study found lower canopy heights in the disturbed forest which may be one of the reasons for the success of C. echinulatum in this particular forest. The variable "fallen wood” appeared to affect the presence of adults of $C$. echinulatum negatively. This result was not expected since adult palms are tall individuals with large diameters and strong stems; however Paredes [49] also reported adult's death as a result of fallen trees.

As expected for $P$. acuminata, light was not as relevant as for $C$. echinulatum given that the former species thrives well in relatively shaded conditions. This result contrasts with the observations by Svenning [55] for the same species. However results have to be interpreted with caution since, as explained before, the best model obtained for adults of this species included variables with $p$-values slightly above the chosen significance level of 0.05 . In this case, a larger sample size would be needed in order to achieve a better understanding of the preferred establishment conditions for $P$. acuminata's adults.

\subsection{Conservation and Management Strategies}

Despite the harvesting pressure that $C$. echinulatum and $P$. acuminata experienced in the past, their establishment and population development is benefited by the environmental conditions found in the disturbed forest. The present study identified important elements that help understanding the preferred environmental conditions of the studied species; information that may be of vital importance for their conservation since it can be applied in the development of sustainable management plans for forest and when analyzing possible impacts of changing environments on populations of the two species. Based on the findings of this study the following management actions are suggested: 1) Steep slopes negatively affect the establishment of the studied species; thus it is recommended to focus management activities on flat areas where palm populations are dense. Populations on steep slopes should be protected as a source of genetic variability for these species; 2) Light benefits the establishment of the majority of the life stages in $C$. echinulatum and $P$. acuminata. Hence, reducing the density of the canopy may be a way to enhance the growth of the species. This method is particularly promising for the first life stages since they are more susceptible to mortality; 3) 
Leaf litter negatively affects the establishment of seedlings in $P$. acuminata. It is therefore recommended to remove part of the leaf litter that covers the seedlings; 4) Connectivity of forest remnants is important for the ability of pollinators and seed dispersers to move between the forests, especially for the dioic species ( $C$. echinulatum). Connectivity also enhances genetic diversity which is important for the species to be resilient to a changing environment; and 5) Forests with different disturbance regimes have different environmental conditions. The present study provides an important first attempt to understand the response of the two palm species to disturbances. Future research should study the population dynamic of $C$. echinulatum and $P$. acuminata in forest remnants of different sizes, as well as the relation of dispersers and pollinators with these palm species.

\section{ACKNOWLEDGEMENTS}

This study was funded by the University of Copenhagen, the Erasmus Mundus Programme of the European Union, and 7th Framework Program "PALMS” (FP-7, grant 212631). We thank Nina Duarte and Inti Llacta family and Sonia Saltos from Rio Bravo for their help during the fieldwork. We also thank Luis Saltos, Juan Lincango, and Manuel for their collaboration during the data collection. D. Rodríguez is grateful to Henrik Balslev for his continuous support. We thank Luis Cárdenas for his technical support with the map.

\section{REFERENCES}

[1] Brokamp, G., Valderrama, N., Mittelbach, M., Grández, C., Barfod, A. and Weigend, M. (2011) Trade in palm products in north-western South America. The Botanical Review, 77, 571-606. doi:10.1007/s12229-011-9087-7

[2] Dransfield, J., Uhl, N., Asmussen, C., Baker, W., Harley M. and Lewis, C. (2008) Genera palmarum: The evolution and classification of palms. Kew Publishing, Royal Botanic Gardens, Kew.

[3] Galetti, M. and Fernández, J. (1998) Palm heart harvesting in the Brazilian Atlantic Forest: Changes in industry structure and the illegal trade. Journal of Applied Ecology, 35, 294-301.

[4] Steffan-Dewenter, I. and Tscharntke, T. (1999) Effects of habitat isolation on pollinator communities and seed set. Oecologia, 121, 432-440. doi:10.1007/s004420050949

[5] Zuidema, P. and Boot, R. (2000) Demographic constraints to sustainable palm heart extraction from a sub-canopy palm in Bolivia. In: Zuidema, P., Ed., Demography of Exploited Tree Species in the Bolivian Amazon, Riberalta: Promab, Chapter 3, Riberalta.

[6] Laurance, W., Ferreira, L., Rankin-De Merona, J., Laurance, S., Hutchings, R. and Lovejoy, T. (1998) Effects of forest fragmentation on recruitment patterns in Amazonian tree communities. Conservation Biology, 12, 460464. doi:10.1046/j.1523-1739.1998.97175.x

[7] Williams-Linera, G. (1990) Vegetation structure and en- vironmental conditions of the forest edges in Panamá. Journal of Ecology, 78, 356-373. doi:10.2307/2261117

[8] Pintaud, J., Galeano, G., Balslev, H., Bernal, R., Borchsenius, F., Ferreira, E., De Granville, J., Mejía, K., Millán, B., Moraes, M., Noblick, L., Stauffer, F. and Kahn, F. (2008) Las palmeras de América del Sur: Diversidad, distribución e historia evolutiva. Revista Peruana de Biología, 15, 7-29.

[9] Borchsenius, F. and Moraes, M. (2006) Diversidad y usos de las palmeras Andinas (Arecaceae). In: Moraes, M., et al. Eds., Botánica económica de los Andes centrales. Universidad Mayor San Andrés, La Paz, Bolivia.

[10] Bonilla, D. and Feil, J. (1995) Production of ramets and germination of Prestoea trichoclada (Arecaceae): A source of palm heart in Ecuador. Principes, 39, 210-214.

[11] Borchsenius, F., Borgtoft-Pedersen, H. and Balslev, H. (1998) Manual to the palms of Ecuador. AAU Reports 37, University of Aarhus, Aarhus.

[12] De La Torre, L., Navarrete, H., Muriel, P., Macia, M. and Balslev, H. (2008) Enciclopedia de las plantas útiles del Ecuador. Herbario QCA de la Escuela de ciencia biológicas de la Pontificia Universidad Católica del Ecuador y Herbario AAU del Departamento de Ciencias Biológicas de la Universidad de Aarhus, Quito and Aarhus.

[13] Pedersen, H. and Balslev, H. (1992) The economic botany of Ecuadorean palms. In: Plotkin, M. and Famolare, L., Eds., Sustainable Harvest and Marketing of Rain Forests Products, Islands Press, Washington DC, 173-191.

[14] Kissling, D.W., Baker, W.J., Balslev, H., Barfod, A.S., Borchsenius, F., Dransfield, J., Govaerts, R. and Svenning, J. (2011) Quaternary and pre-quaternary historical legacies in the global distribution of a major tropical plant lineage. Global Ecology and Biogeography, 21, 909-921.

[15] Svenning, J. (2001) On the role of micro-environmental heterogeneity in the ecology and diversification of neotropical Rain-forest palms (Arecaceae). Botanical Review, 67, 1-53. doi:10.1007/BF02857848

[16] Skov, F. and Borchsenius, F. (1997) Predicting plant species distribution patterns using simple climatic parameters: A case study of Ecuadorean palms. Ecography, 20, 347-355. doi:10.1111/j.1600-0587.1997.tb00379.x

[17] Henderson, A. (1995) The palms of the Amazon. Oxford University Press, Oxford. doi:10.1126/science.165.3889.131

[18] Haffer, J. (1969) Speciation in Amazonian forest birds. Science, 165, 131-137. doi:10.1126/science.165.3889.131

[19] Montúfar, R. and Pintaud, J. (2006) Variation in species composition, abundance and microhabitat preferences among western Amazonian terra firme palm communities. Botanical Journal of the Linnean Society, 151, 127-140. doi:10.1111/j.1095-8339.2006.00528.x

[20] Clark, D., Clark, D., Sandoval, M. and Castro M. (1995) Edaphic and human effects on landscape-scale distributions of tropical rain forest palms. Ecology, 76, 25812594. doi:10.2307/2265829

[21] Svenning, J. (1999) Microhabitat specialization in a species-rich palm community in Amazonian Ecuador. Journal of Ecology, 87, 55-65. 
doi:10.1046/j.1365-2745.1999.00329.x

[22] Vormisto, J., Hanna, T. and Jari, O. (2004) Palm distribution patterns in Amazonian rainforests: What is the role of topographic variation. Journal of Vegetation Science, 15, 485-494. doi:10.1111/j.1654-1103.2004.tb02287.x

[23] Karubian, J., Sork, V. L., Roorda, T., Duraes, R. and Smith, T. (2010) Destination-based seed dispersal homogenizes genetic structure of a tropical palm. Molecular Ecology, 19, 1745-1753. doi:10.1111/j.1365-294X.2010.04600.x

[24] Souza, A. and Martins, F. (2004) Microsite specialization and spatial distribution of Geonoma brevispatha a clonal palm in south-eastern Brazil. Ecological Research, 19, 521532. doi:10.1111/j.1440-1703.2004.00670.x

[25] Svenning, J. (2000). Small canopy gaps influence plant distributions in the rain forest understory. Biotropica, 32, 252-261.

[26] Bubb, P., May, I., Miles, L. and Sayer, J. (2004) Cloud forest.

http://www.unep-wcmc.org/resources/publications/UNEP _WCMC_bio_series/20.htm

[27] Cuesta, F., Peralvo, M. and Valarezo, N. (2009) Los bosques montanos de los Andes Tropicales. Una evaluación regional de su estado de conservación y de su vulnerabilidad a efectos del cambio climático. Programa Regional ECOBONA-Intercooperation, Imprenta Mariscal, Quito.

[28] Josse, C., Cuesta, F., Navarro, G., Barrena, V., Cabrera, E., Chacón-Moreno, E., Ferreira, W., Peralvo, M., Saito, J. and Tovar, A. (2009) Ecosistemas de los Andes del Norte y Centro. Bolivia, Colombia, Ecuador, Perú y Venezuela. Secretaría General de la Comunidad Andina, programa Regional ecobona-intercooperation, codesan-proyecto páramo andino, programa bio-andes, ecociencia, nature serve, iavh, lta-unalm, icae-ula, cdc-unalm, rumbol srl. Lima.

[29] Montúfar, R., Anthelme, F., Pintaud, J. and Balslev, H. (2011) Disturbance and resilience in tropical American palm populations and communities. Botanical Review, 77, 426-461. doi:10.1007/s12229-011-9085-9

[30] Kapos, V. (1989) Effects of isolation on the water status of forest patches in the Brazilian Amazon. Journal of Tropical Ecology, 5, 173-185. doi:10.1017/S0266467400003448

[31] Laurance, W., Ferreira, L., Rankin-De Merona, J. and Laurence, S. (1998) Rain forest fragmentation and the dynamics of Amazonian tree communities. Ecology, 79, 2032-2040. doi:10.1890/0012-9658(1998)079[2032:RFFATD]2.0.CO ;2

[32] Tomlinson, P. (1990) The structural biology of palms. Oxford University Press, New York.

[33] Anthelme, F., Lincango, J., Gully, C., Duarte, N. and Montúfar, R. (2011) How anthropogenic disturbances affect the resilience of a keystone palm tree in the threatened Andean cloud forest. Biological Conservation, 144, 10591067. doi:10.1016/j.biocon.2010.12.025

[34] Guevara, M., Fuentes-Pozo, P., Josse, C. and Peñafiel, M. (2001) Tres décadas de cambios en el uso de la tierra en el área de Nanegal. In: Rhoades, R.E., Ed., Tendiendo puentes entre los paisajes humanos y naturales. La investigación participativa y el desarrollo ecológico en una frontera agrícola andina, Abya Yala, Quito, 416.

[35] Jensen, A. and Meilby, H. (2008) Does commercialization of non-timber forest product reduce ecological impact. A case study of critically endangered aquilaria crassna in Lao PDR. Oryx, 42, 214-221. doi:10.1017/S0030605308007825

[36] Cañadas-Cruz, L. (1983) El mapa bioclimático y ecológico del Ecuador. Banco Central del Ecuador. Quito, Ecuador.

[37] Knudsen, H. (1995) Demography, palm-heart extractivism, and reproductive biology of P. acuminata (Arecaceae) M.Sc. Thesis, Department of Systematic Botany, University of Aarhus, Aarhus.

[38] Sanín, M. J. and Galeano, G. (2011). A revision of the andean wax palm, Ceroxylon (Arecaceae). Phytotaxa, 34, 164.

[39] Henderson, A., Galeano, G. and Bernal, R. (1995) Field guide to the palms of the Americas. Princenton University Press, New Jersey.

[40] Daws, M., Pearson, T., Burslem, D., Mullins, C. and Dalling, J. (2005) Effects of topographic position, leaf litter and seed size on seedling demography in a semi-deciduous tropical forest in Panamá. Plant Ecology, 179, 93-105. doi:10.1007/s11258-004-5801-4

[41] Brown, N., Jennings, S., Wheeler, P. and Nabe-Nielsen, J. (2000) An improved method for the rapid assessment of the forest understorey light environments. Journal of Applied Ecology, 37, 1044-1053. doi:10.1046/j.1365-2664.2000.00573.x

[42] Svenning, J. (1998) The effect of land-use on the local distribution of palm species in an Andean rain forest fragment in northwestern Ecuador. Biodiversity and Conservation, 7, 1529-1537. doi:10.1023/A:1008831600795

[43] Madriñán, S. and Schultes, R. (1995) Colombia’s national tree: The wax palm Ceroxylon quindiuense and its relatives. Elaeis, 7, 35-56.

[44] Molofsky, J. and Augspurger, C. (1992) The effects of leaf litter on early seedling establishment in a tropical forest. Ecology, 73, 68-77. doi:10.2307/1938721

[45] Vázquez-Yanes, C., Orozco-Segovia, A., Rincón, E., Sánchez-Coronado, M., Huante, P., Toledo, J. and Barradas, V. (1990) Light beneath the litter in a tropical forest: Effect on seed germination. Ecology, 71, 1952-1958. doi:10.2307/1937603

[46] Cintra, R. (1997) Leaf litter effects on seed and seedling predation of the palm Astrocaryum murumuru and the legume tree Dypteryx micrantha in Amazonian forest. Journal of Tropical Ecology, 13, 709-725. doi:10.1017/S0266467400010889

[47] Rudas, C. (1998) Evaluación del estado actual de una población de la palma de cera, Ceroxylon sasaimae Galeano: Aportes a su historia de vida y estudio demográfico. B.Sc. Thesis, Universidad de Los Andes, Bogotá.

[48] Didham, R. and Lawton, J. (1999) Edge structure determines the magnitude of changes in microclimate and vegetation structure in tropical forests fragments. Bio- 
tropica, 31, 17-30.

[49] Paredes, T. (1995) Primeros estudios biológicos de la palma de ramos (Ceroxylon echinulatum) presente en Cosanga (provincia del Napo) entre Agosto de 1991 y Octubre de 1992. Tesis de Licenciatura, Departamento de Biología, Pontificia Universidad Católica del Ecuador, Quito.

[50] Schupp, E. (1992) The janzen-connell model for tropical tree diversity: Population implications and the importance of spatial scale. The American Naturalist, 140, 526-530. doi:10.1086/285426

[51] Kahn, F. (1986) Life forms of Amazonian palms in relation to forest structure and dynamics. Biotropica, 18, 214218. doi:10.2307/2388487

[52] Svenning, J. (1999) Recruitment of tall arborescent palms in the Yasuní National Park, Amazonian Ecuador: Are large treefall gaps important. Journal of Tropical Ecology, 15, 355-366. doi:10.1017/S0266467499000875

[53] Svenning, J. (2000) Growth strategies of clonal palms (Arecaceae) in a neotropical rainforest, Yasuní, Ecuador.
Australian Journal of Botany, 48, 167-178. doi:10.1071/BT98048

[54] Galeano, G. (1995) Novedades del género Ceroxylon (Palmae). Caldasia, 17, 395-408.

[55] Svenning, J. (2001) Environmental heterogeneity, recruitment limitation and the mesoscale distribution of palms in a tropical montane rain forest (Maquipucuna, Ecuador). Journal of Tropical Ecology, 17, 97-113. doi:10.1017/S0266467401001067

[56] Henderson, A. (2002) Evolution and ecology of palms. The New York Botanical Garden press, New York.

[57] Lugo, A. and Rivera, C. (1987) Leaf production, growth rate, and age of the palm Prestoea Montana in the Luquillo experimental forest, Puerto Rico. Journal of Tropical Ecology, 3, 151-161. doi:10.1017/S0266467400001905

[58] Vergara, L. (2002) Demografía de ceroxylon alpinum en bosques relictuales del Valle de Cocora, Salento (Quindio). B.Sc. Thesis, Departamento de Biología, Universidad Nacional de Colombia, Bogotá. 